\title{
POST-COMMUNIST COUNTRIES OF THE EU AND THE EURO: DYNAMIC LINKAGES BETWEEN EXCHANGE RATES*
}

\author{
Nikolaos STOUPOS - Apostolos KIOHOS \\ (Received: 22 November 2016; revised: 8 August 2017; \\ accepted: 20 August 2017)
}

\begin{abstract}
The sovereign debt crisis of 2010 in the euro area significantly decelerated the monetary integration of the EU. The main purpose of this paper is to explore whether five post-communist member states of the EU are mature enough to adopt the euro. We used nominal exchange rates in the error correction model with asymmetric power ARCH (ECM-APARCH). Our results highlight that EU membership positively increased the impact of the euro on the currency of each of these countries in the short-run. In contrast, the long-term effect of the euro on each currency is negative for the Czech Republic, Hungary, and Croatia. Wholly different results were obtained for Poland and Romania. The APARCH model showed that the negative responses of the euro had a greater or neutral effect on the conditional variance of each currency instead of the positive responses. The debt crisis of the euro area had no impact on the dynamic linkages between the currencies. Our research concludes that Croatia, the Czech Republic, and Hungary are not ready to join the euro area in the near future. On the other hand, the currencies of Poland and Romania are already aligned with the fluctuations of the euro.
\end{abstract}

Keywords: volatility, exchange rates, ECM-APARCH, linkages, euro zone enlargement, post-communist economies, rolling regression, EU unification

JEL classification indices: C13, F3, F31, G15, G17, G32

* We are especially grateful to the referees of Acta Oeconomica for their comments, as well as to Associate Professor George Filis (Bournemouth University, UK) for his continuous aid, support, and guidance during the completion of this research.

Nikolaos Stoupos, corresponding author. Ph.D. candidate, Department of International and European Studies, University of Macedonia, Thessaloniki, Greece, E-mail: nikostoupos@gmail.com

Apostolos Kiohos, Assistant Professor, Department of International and European Studies, University of Macedonia, Thessaloniki, Greece. E-mail: akiohos@uom.gr, akiohos@otenet.gr 


\section{INTRODUCTION}

The aim of our research is to explore whether the euro zone should accept further members from among the post-communist countries. Or, to put it differently, are these countries ready to join the euro zone?

We observed the nominal exchange rate movements of the euro against the US dollar in order to discover whether there are possible dynamic linkages with the nominal exchange rate of each currency against the US dollar. We used the nominal exchange rate as an empirical tool because the currencies reflect the real condition of an economy based on the methodology of Wilfling (2009), who also used nominal exchange rates in order to examine the volatility regime-switching in European exchange rates prior to the monetary union of 1999. Particularly, his data consisted of daily spot exchange rates of 16 currencies vis-à-vis the German mark (DEM) (January 1, 1996, to December 31, 1998) and the euro (January 1, 1999 to December 31, 2006). Also, he used the univariate Markov-switching GARCH dispersion model in order to calculate the volatility term. His findings suggest that volatility regime-switching models provide a useful tool for a broad range of financial applications for future European Monetary Union (EMU) members (Wilfling 2009).

Stoupos - Kiohos (2017) used the nominal exchange rates of three leading currencies of Europe in order to explore the monetary integration of the EU in the UK, Switzerland, and Sweden. They combined the error correction model (ECM) with exponential generalised autoregressive conditional heteroskedasticity (EGARCH) and ECM-EGARCH. Their results showed that from a financial viewpoint, the UK should not join the euro. Switzerland shows historically an exchange rate independence from the euro, but there are recent indications that support the opposite direction. Additionally, the results suggested that Sweden should join the euro zone because there is a strong historical linkage between the euro and the Swedish koruna.

In this paper, we investigate the behaviour of the currencies of the Czech Republic, Croatia, Hungary, Poland, and Romania because at present they do not peg their national currencies with the euro. We use an innovative econometric approach by combining ECM (Engle - Granger 1987) with the asymmetric power autoregressive conditional heteroskedasticity (APARCH) model (Ding et al. 1993). Particularly, we use ECM as the mean equation of the ARCH model and the APARCH model as the variance equation. The errors of the ECM model will help us to examine volatility persistency, volatility asymmetry, and leverage effect. Finally, the use of rolling regression will be shown as an auxiliary methodology to ECM.

ECM is an advanced econometric model that provides short- and long-term dynamics among a group of variables. The most important component for our 
research is the long-term coefficient. If positive, it means that the reaction of the nominal exchange rate of the euro has a positive impact on each examined post-communist currency. The first research hypothesis is related to the ECM. Therefore, we test the following null and alternative hypotheses.

$\mathrm{H}_{01}$ : the long-term impact of the euro would be positive on each post-communist currency.

$\mathrm{H}_{11}$ : the long-term impact of the euro would be not positive on each postcommunist currency.

Moreover, the APARCH model is suitable for examining volatility asymmetry, volatility persistence, and leverage effect. In fact, the use of the APARCH model is very useful in order to find out the resistance (volatility asymmetry and persistence) of each examined variable against the financial or economic shocks of the euro. Additionally, the leverage effect is related to the impact of good news (overvaluation of the euro) and bad news (devaluation of the euro) on the economic behaviour of the examined currencies. Consequently, we would discover whether the examined currencies are vulnerable against the shocks of the euro's market reaction. Hence, the second and third research hypotheses are linked with the APARCH model. We test the following null and alternative hypotheses.

$\mathrm{H}_{02}$ : The examined currencies would be vulnerable against the economic/financial shocks of the euro.

$\mathrm{H}_{12}$ : The examined currencies would be not vulnerable against the economic/ financial shocks of the euro.

and

$\mathrm{H}_{03}$ : The overvaluation of the euro would influence more the nominal exchange rate of each currency than the devaluation of the euro.

$\mathrm{H}_{13}$ : The overvaluation of the euro would not influence more the nominal exchange rate of each currency than the devaluation of the euro.

Actually, the three above research hypotheses present the main purposes of the current empirical study. At the end of this paper, we describe whether they are true according to our empirical evidence.

At the end, if we discover that the three hypotheses are true simultaneously, then we could claim that the economic behaviour of the examined currency follows the economic reactions of the European common currency. Therefore, we may ask, "Why don't these countries enter the EMU, since they have unofficially already adopted the euro from a financial aspect?"

The rest of the paper is organised as follows. Section 2 presents our data. Section 3 includes the methodology, and Section 4 presents the preliminary diagnostics tests (unit root test and co-integration test). Section 5 includes the empirical results of the combined methodology, ECM-APARCH, and Section 6 concludes. 


\section{DATASET ANALYSIS}

We used the nominal exchange rates of five new EU member states which have not yet adopted the euro. Specifically, we attempted to investigate whether there are possible linkages between the euro, the Czech koruna, the Croatian kuna, the Hungarian forint, the Polish zloty, and the Romanian leu. The data were collected from the official database of the European Central Bank (ECB). The nominal exchange rate of each currency is expressed in US dollars (USD) because the US dollar is historically the most traded currency in the world (JP Morgan 2009). We used the nominal exchange rate instead of the real exchange rate because we wanted to include the actual reaction of the global financial markets. We used daily observations from January 1, 1999, to December 31, 2016, by covering a range of 18 continuous years. We divided the dataset into three sub-periods. The cutting points were designed by using the unit root testing of Lee - Strazicich (2003) which reveals the structural breaks endogenously from the data and indicates if the breaks exist only in the intercept, or both in the intercept and the trend of the series.

\section{The three sub-periods are the following:}

a) January 1, 1999, to February 28, 2002

None of our countries was a member of the EU, but they had already submitted the official application to the European Commission (EC). During this period, the euro area decision-makers were preoccupied with the creation and the regular operation of the EMU.

b) March 1, 2002, to April 30, 2010

During this period, the Czech Republic, Hungary, Poland, and Romania joined the EU. This period is characterised by a financial prosperity in Europe until 2008 when the global financial crisis broke out. The European crisis occurred in May 2010, with emergences of the euro zone debt crisis. In 2010, after months of frantic diplomatic negotiations, the IMF, the EC, and the ECB hammered out a three-year package to rescue Greece. Greece was the first member of the euro area which asked for the financial assistance and solidarity of the other members of the euro zone.

c) May 1, 2010, to December 31, 2016

This period is historically known as the debt crisis in the Euro Area. The euro zone and the EU were under structural reform for the establishment of the European Banking Union, the European Financial Stability Facility (EFSF), and the European Stability Mechanism (ESM). In addition, Greece signed three Memoranda of Understanding (MoU). Portugal, Ireland, and Cyprus signed only one MoU. During this period, the non-euro countries of the EU had plenty of second thoughts about their participation in the euro area. 
Table 1. Exchange rate regimes in the post-communist countries of the EU

\begin{tabular}{ll}
\hline Countries & \multicolumn{1}{c}{ Regime } \\
\hline Croatia & Currency pegged with DEM (subsequently EUR) from 1998 (Managed float) \\
Czech Republic & Fixed peg against basket 65\% DEM, 35\% USD from March 1997 \\
& Managed float against EUR from March 1997 \\
Hungary & Peg to basket 50\% ECU, 50\% USD \\
& Basket changed to 50\% DEM, 50\% USD from August 1993 \\
& Basket changed to 70\% ECU, 30\% USD from May 1994 \\
& Crawling peg/band to basket from March 1995 \\
& Basket changed to 70\% EUR, 30\% USD from January 1999 \\
& Basket changed to 100\% EUR from January 2000 \\
& Fixed to USD from January 1990 \\
Poland & Fixed to basket (45\% USD, 55\% DEM + GBP + FF + CHF) from May 1991 \\
& Crawling peg to (same) basket \\
& Basket changed to 55\% EUR, 45\% USD from January 1999 \\
& Free float (but Central Bank reserves extraordinary right to intervene) from \\
Romania & April 2000 \\
\hline
\end{tabular}

Source: IMF (2015); Maican - Sweeny (2013).

\section{METHODOLOGY}

We produced two diagnostics tests and a combination of ECM with the APARCH model. Initially, we used the Lee - Strazicich (2003) stationarity test in order to explore whether the time series have unit roots. The main feature of this test is that it finds the structural breaks in the time series. The second diagnostic test is Johansen's co-integration test with structural breaks with a deterministic trend. The use of this test is prerequisite in order to investigate whether the time series are co-integrated in the long run (Johansen et al. 2000).

The first basic model of our analysis is the ECM, which is suitable to be used only if the time series are co-integrated $\sim \mathrm{I}(1)$. The main characteristic of the ECM is that it explores dynamic short-term and long-term linkages between groups of variables (Engle - Granger 1987). In our case, we used the natural logarithmic values of the nominal exchange rates in order to capture the possible linkages between them. The use of the natural logarithmic values lends higher consistency, stability, and predictability to our model.

We then used the rolling regression (refitted and restored) methodology in order to compare the results of the ECM. Specifically, RR approaches ${ }^{1}$ are often used in time series analysis to assess the stability of the model parameters with respect to time. A common assumption of time series analysis is that the mod-

Also known as rolling window, recursive regression, or reverse recursive regression. 
el parameters are time-invariant. However, as the economic environment often changes, it may be reasonable to examine whether the model parameters are also constant over time (Banerjee et al. 1992). One technique to assess the constancy of the model parameters is to compute the parameter estimates over a rolling window with a fixed sample size through the entire sample. If the parameters are truly constant over the entire sample, the rolling estimates over the rolling windows will not change much. If the parameters change at some point in the sample, the rolling estimates will show how the estimates have changed over time (Banerjee et al. 1992).

In order to capture the volatility of the exchange risk among the nominal exchange rates, we utilised the APARCH model (Ding et al. 1993). The APARCH model is suitable for exploring volatility asymmetry, leverage effect, and volatility persistence. Particularly, we used the ECM as the mean equation and the APARCH model as the variance equation (Gaussian errors distribution). This methodology combination creates our innovative ECM-APARCH model.

\subsection{The Error Correction Model (ECM)}

The general mathematic formula of ECM according to Engle - Granger (1987) is as follows:

$$
\Delta \Upsilon_{t}=\omega+\varphi E C_{t-1} \sum_{i=1}^{p} \psi_{i} \Delta \Upsilon_{t}+\sum_{j=0}^{q} \theta_{j} \Delta X_{t-j}+\varepsilon_{t}
$$

where $\varphi$ presents the adjustment speed back to equilibrium, $\psi$ expresses the shortterm dynamics coefficient, and $\theta$ displays the long-term dynamics coefficient.

We used the following multivariate model in order to explore short-term and long-term dynamics among the examined variables:

$$
\Delta\left(\ln \left(C U R_{t}\right)\right)=\omega+\varphi E C_{1}(t-1)+\psi \Delta\left(\ln \left(C U R_{t-1}\right)\right)+\theta\left(\Delta\left(\ln \left(E U R_{t-1}\right)\right)+\varepsilon_{t}\right.
$$

where the dependent variable $\ln C U R_{t}$ represents the natural logarithmic value of the nominal exchange rate of the Czech koruna (CZK), the Croatian kuna (HRK), the Hungarian forint (HUF), the Polish zloty (PLN), or the Romanian leu (RON) against the US dollar (USD). The independent variable $\left(\ln E U R_{t}\right)$ is the natural logarithmic value of the nominal exchange rate of the euro (EUR) against the US dollar (USD). 


\subsection{The Asymmetric Power ARCH model (APARCH)}

The Asymmetric Power ARCH model (APARCH) was developed by Ding et al. (1993). The APARCH model includes volatility asymmetry, leverage effect, and volatility persistence. The conditional variance of an APARCH model is specified as follows:

$$
\sigma_{t}^{\delta}=\omega \sum_{i=1}^{p} \alpha\left(\left|\varepsilon_{t-i}\right|-\gamma_{i} \varepsilon_{t-i}\right)^{\delta}+\sum_{j=1}^{q} \beta_{j} \sigma_{t-i}^{\delta}
$$

where parameter $\alpha$ represents volatility asymmetry, parameter $\beta$ displays the volatility persistence, parameter $\gamma$ shows the leverage effect, and parameter $\delta$ is the power of the APARCH model.

The restrictions for the positivity of $\sigma_{t}^{\delta}$ are given by Ding et al. (1993) as follows:

$$
\omega>0, \geq 0,-1<\gamma<1, \alpha \geq 0 \text { and } \beta \geq 0 .
$$

The $\delta$ parameter is very important because it nests plenty of other volatility models.

In specific, we obtain an/a:

ARCH model if $\delta=2, \gamma=0, \beta=0$ and $\alpha \neq 0$ (Engle 1983)

GARCH model if $\delta=2, \gamma=0, \beta \neq 0$ and $\alpha \neq 0$ (Bollerslev 1986)

GJR-GARCH model if $\delta=2, \gamma \neq 0, \beta \neq 0$ and $\alpha \neq 0$ (Glosten et al. 1993)

TGARCH model if $\delta=1, \gamma \neq 0, \beta \neq 0$ and $\alpha \neq 0$ (Zakoian 1991)

NARCH model if $\delta=1, \gamma=0, \beta=0$ and $\alpha \neq 0$ (Bera - Higgins 1992)

\section{DIAGNOSTICS TESTS}

\subsection{Lee - Strazicich unit root test with breakpoints}

The exploration of a random walk (unit root) is very important in time series analysis. A stationarity test is requisite before executing a co-integration test. We ran a Lee - Strazicich (2003) two breakpoints stationarity test. We included an intercept and a trend in test equation. The Lee - Strazicich test was executed by using the natural logarithmic value of the nominal exchange rates of each currency 
Table 2. Estimation results of Lee - Strazicich unit root test

\begin{tabular}{lcc}
\hline Series - in values & t-statistic & Probability \\
\hline Euro & $-3.03^{*}$ & $0.036^{*}$ \\
Czech koruna & $-2.89^{*}$ & $0.021^{*}$ \\
Croatian kuna & $-3.03^{*}$ & $0.036^{*}$ \\
Hungarian forint & $-3.53^{*}$ & $0.047^{*}$ \\
Polish zloty & $-3.87^{*}$ & $0.001^{*}$ \\
Romanian leu & $-4.23^{*}$ & $0.001^{*}$ \\
\hline
\end{tabular}

Note: * denotes statistically significant at the $0.05 \%$ level.

(Table 2). We discovered that time series are stationary according to $t$-statistic and probability value criteria.

Figure 1 shows the two breakpoints of each time series that we used. The main characteristic of each time series is that the first break point is the same (around May 1, 2010). Also, the majority of the time series present a second break point at around March 1, 2002. Therefore, we have selected these dates as the two breakpoints in order to create the three sub periods that we have already described in Section 2. The breakpoints are presented with the use of arrows.

\subsection{Johansen's Co-integration Test with structural breaks}

The Johansen co-integration test with structural breaks is based on a model which allows for any pre-specified number of sample periods $(q)$ of length $T_{j}-T_{j-1}$ for $j=1, \ldots, q$ and $0=T_{0}<T_{1}<T_{2}<\ldots<T_{q}=T$. It follows that the last observation in the $j$ th sample is $T_{j}$, while $T_{j+1}$ is the first observation in sample period number $(j+1)$. A vector autoregressive model of order $k$ is considered. In analogy with the usual models without structural breaks, the model is formulated conditionally on the first $k$ observations of each sub-sample, $X T_{j-1}+1, \ldots, X T_{j-1}+k$, and it is given by the equations

$$
\Delta X_{t}=\left(\Pi, \Pi_{j}\right)\left(\begin{array}{c}
X_{t-1} \\
t
\end{array}\right)+\mu_{j}+\sum_{t=1}^{k-1} \Gamma_{i} \Delta X_{t-1}+\varepsilon_{t}
$$

for $j=1, \ldots, q$ and $T_{j-1}+k<t \leq T_{j}$. The innovations are assumed to be independently, identically normally distributed with mean zero and variance $\Omega$. The parameters vary freely, so $\Pi, \Gamma_{i}$, and $\Omega$, which relate to the stochastic component

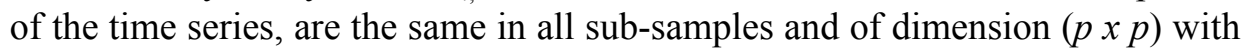
$\Omega$ being symmetric and positive definite, while the $p$-vectors $\Pi_{j}$ and $\mu_{j}$ relate to the deterministic component and could be different in different sample periods (Johansen et al. 2000). 

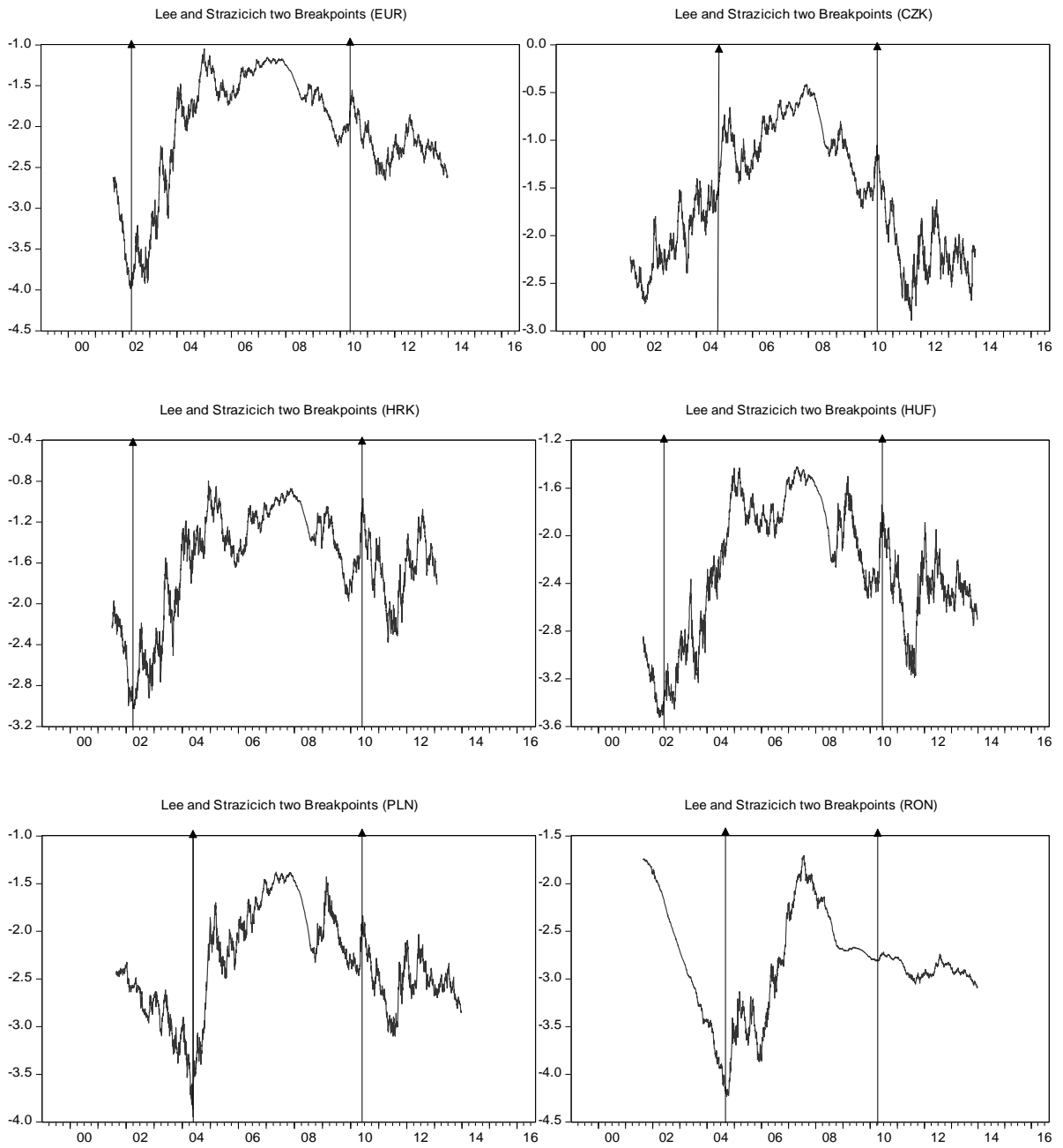

Figure 1. Lee - Strazicich breakpoints unit root test

Table 3 displays the empirical results of the co-integration test. We used the natural logarithmic value of each currency in order to discover whether the series are co-integrated in the long run. We selected the deterministic trend assumption of the test that there is a trend and an intercept in co-integrating equations (CE) and no intercept in VAR with three lags according to the Schwarz criterion. The results of Johansen co-integration testing with structural breaks for the countries included in our research are presented in Table 3. 
Table 3. Johansen's Co-integration Structural Breaks Tests CZK vs. EUR

\begin{tabular}{lclcc}
\hline Hypothesised No. of CE(s) & Total Period & $1^{\text {st }}$ Period & $2^{\text {nd }}$ Period & $3^{\text {rd }}$ Period \\
\hline None & $0.0921^{* *}$ & $0.0005^{*}$ & $0.0117^{*}$ & $0.0097^{*}$ \\
At most 1 & 0.1131 & $0.0877^{* *}$ & 0.2058 & $0.0246^{*}$ \\
HRK $v$ s. EUR & & & & \\
\hline Hypothesised No. of CE(s) & Total Period & 1 st Period & 2 nd Period & 3rd Period \\
\hline None & $0.0181^{*}$ & $0.0209^{*}$ & $0.0470^{*}$ & $0.0418^{*}$ \\
At most 1 & 0.0846 & 0.2581 & 0.1157 & 0.0833 \\
HUF $v$ s. EUR & & & & \\
\hline Hypothesised No. of CE(s) & Total Period & 1 st Period & 2 nd Period & 3rd Period \\
\hline None & $0.0871^{* *}$ & $0.0979^{* *}$ & $0.0102^{*}$ & $0.0498^{*}$ \\
At most 1 & 0.9376 & 0.5634 & 0.0716 & 0.3800 \\
PLN $v s$. EUR & & & & \\
\hline Hypothesised No. of CE(s) & Total Period & 1 st Period & 2 nd Period & 3 rd Period \\
\hline None & $0.0789^{* *}$ & $0.0079^{*}$ & $0.0465^{*}$ & $0.0412^{*}$ \\
At most 1 & 0.3505 & 0.0813 & 0.1911 & 0.2256 \\
RON $v$ s. EUR & & & & \\
\hline Hypothesised No. of CE(s) & Total Period & 1 st Period & 2 nd Period & 3rd Period \\
\hline None & $0.0000^{*}$ & $0.0050^{*}$ & $0.0365^{*}$ & $0.0204^{*}$ \\
At most 1 & 0.1711 & 0.2175 & 0.1265 & 0.1930 \\
\hline
\end{tabular}

Note: $*$ statistically significant at the $0.05 \%$ level, ** at the $0.1 \%$ level.

\section{EMPIRICAL RESULTS}

\subsection{Error Correction Model (ECM) and Rolling Regression (RR) results}

\section{Czech Republic}

The ECM shows short-term and long-term dynamics among the natural logarithmic values of the nominal exchange rates (Table 4). The dependent variable is the natural logarithmic value of the CZK/USD. The independent variable is the natural logarithmic value of the nominal exchange rate of the euro against the US dollar. The $t$-statistic values are in the parentheses. Note, that all the diagnostic tests show that there is no autocorrelation. The majority of coefficients are statistically significant. Particularly, the euro influences slightly positively the nominal exchange rate of the CZK/USD in the short run. We observe that EU membership increased the short-term impact of the euro on the Czech koruna, especially during the second and the third period. It may have happened because the Czech National Bank/Ceska Narodni Banka (CNB) followed the same monetary policy as the ECB from 2004 to 2016. Also, the euro seems to have had no impact on 
Table 4. Estimation results of ECM - CZK vs. EUR

\begin{tabular}{lcccc}
\hline Parameter & Total period & $1^{\text {st }}$ period & $2^{\text {nd }}$ period & $3^{\text {rd }}$ period \\
$\omega$ & -0.001 & -0.001 & -0.001 & 0.001 \\
& $(-0.35)^{*}$ & $(-0.60)$ & $(1.63)$ & $(2.02)^{*}$ \\
$\psi$ & 0.070 & -0.20 & 0.164 & 0.109 \\
& $(2.34)^{*}$ & $(-2.76)^{*}$ & $(4.12)^{*}$ & $(1.98)^{*}$ \\
$\varphi$ & 0.002 & 0.007 & 0.001 & 0.007 \\
$\theta$ & $(1.38)$ & $(2.64)^{*}$ & $(0.18)$ & $(1.94)^{*}$ \\
& -0.071 & 0.115 & -0.169 & 0.093 \\
& $(-2.02)^{*}$ & $(1.54)$ & $(-3.46)^{*}$ & $(-1.25)$ \\
\hline
\end{tabular}

Note: * statistically significant at the 0.05 level. $0.05 \%$

the Czech koruna when the Czech Republic was not a member of the EU (during the first period). The long-term impact of the euro is slightly negative during the total period. During the $1^{\text {st }}$ and the $3^{\text {rd }}$ period, the euro had no impact on the Czech koruna.

The long-term impact changes to negative during the $2^{\text {nd }}$ period. It may occur because the CNB kept a lid on the koruna since 2013 and intervened with increased regularity over the last year to hold the exchange rate on the weak side of 27 koruna per euro as the country's economy has thrived. In addition, the CNB introduced a temporary exchange rate targeting policy in 2015. Since then, the $\mathrm{CZK}$ is on a completely different path from that of the euro. But one plausible interpretation is that the CNB had an additional tool to fight zero lower bound that was not available for the ECB. Also, the CNB's ex-governor expected to remove the cap around mid-2018, but after a change of guard at the Czech Central Bank and with increasing wage pressure expected to fire up inflation, traders are looking more closely at the timing of the move. The new CNB governor has announced that the weak koruna policy could end around mid-2017 even if inflation is still slightly below the bank's $2 \%$ target, but is heading higher (Muller Hovet 2017). Finally, CNB has removed its upper limit on the koruna after three and a half years at an extraordinary meeting, highlighting how the rise in inflation across the region is prompting change in long-standing central bank policies (Martin 2017). In April 2015, the Czech coalition government announced that it had agreed not to set a euro adoption target and not to enter ERM II before the next legislative election scheduled for October 2017, making it unlikely that the Czech Republic will adopt the euro before 2020 (Harper 2017).

Figure 2 presents the results of the rolling regression for the Czech Republic. The rolling regression shows that the short-term dynamics coefficient is positive during the examined period. However, it changed to negative from 2006 to 2008 and from 2015 to 2016 . The tendency is strictly negative during the last period. On the other hand, the long-term dynamics coefficient follows a different 

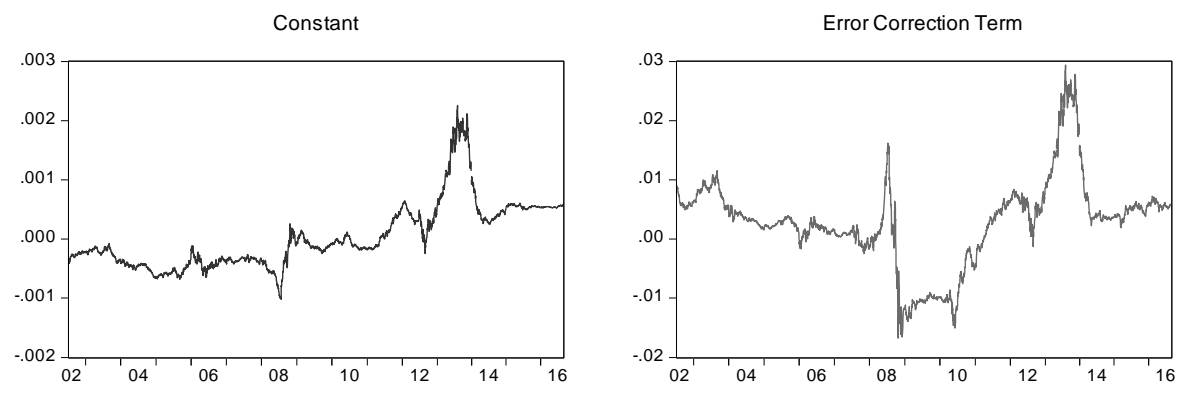

Short-term dymanics

Long-term Dynamics
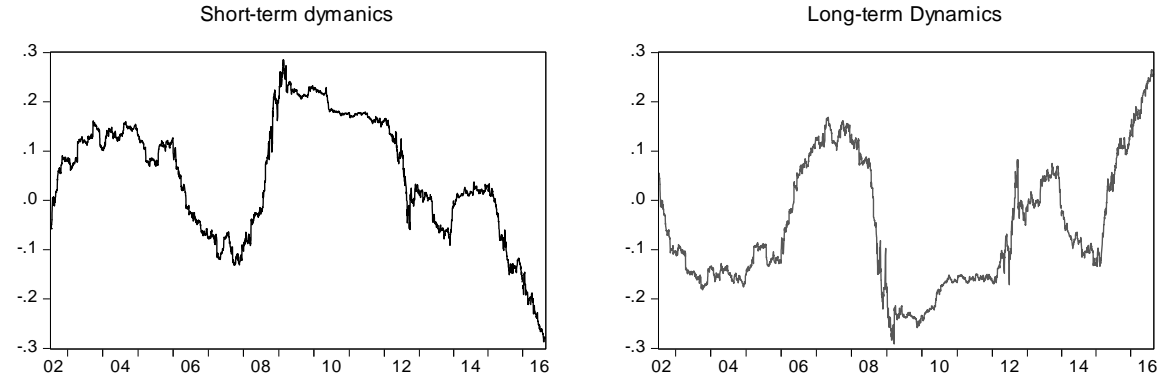

Figure 2. Rolling Regression Results of ECM (Czech Republic)

behaviour. Its value is negative during the largest part of the examined period. However, we observe that the long-term tendency between the euro and the CZK seems to be positive from 2015 to 2016 . Consequently, we could think that the Czech Republic is not ready to adopt the euro. Regarding the similar interest rate policy that both central banks have followed, the null relationship between these two currencies means that the CZK does not follow the long-term economic behaviour of the euro.

\section{Croatia}

Table 5 presents the results of the ECM for Croatia. The model is the same as before. The constant is not statistically significant for either period. The short-term effect of the euro on the Croatian kuna (HRK) is positive among the periods, but its tendency decreases through time. On the other hand, the long-term impact of the euro on HRK is negative during each period, which weakens through time. The above is obvious because Croatia became a member of the EU on July 1, 2013.

During the $2^{\text {nd }}$ period, the long-term impact is negative. This may be due to the decision of the governor of the Croatian National Bank to reject a euro-peg. He decided to implement the official agreement of that time, which permitted 
Table 5. Estimation Results of ECM - HRK vs. EUR

\begin{tabular}{lcccc}
\hline Parameter & Total period & $1^{\text {st }}$ period & $2^{\text {nd }}$ period & $3^{\text {rd }}$ period \\
$\omega$ & -0.001 & 0.001 & -0.001 & -0.001 \\
& $(-0.30)$ & $(0.78)$ & $(1.93)$ & $(-0.06)$ \\
$\psi$ & 0.092 & 0.228 & 0.193 & 0.102 \\
& $(2.52)^{*}$ & $(2.61)^{*}$ & $(2.42)^{*}$ & $(2.72)^{*}$ \\
$\varphi$ & 0.004 & 0.012 & -0.014 & -0.01 \\
& $(0.95)$ & $(0.74)$ & $(-1.42)$ & $(-1.20)$ \\
$\theta$ & -0.12 & -0.34 & -0.19 & -0.10 \\
& $(-2.01)^{*}$ & $(-2.32)^{*}$ & $(2.31)^{*}$ & $(-2.72)^{*}$ \\
\hline
\end{tabular}

Note: * statistically significant at the $0.05 \%$ level.

the kuna to float against the euro within a 15\% "price corridor", this could not be preserved unless market forces were restrained (Jansson 2005). In particular, the Croatian National Bank (Hrvatska Narodna Banka) began to follow a similar monetary policy as the ECB, after Croatia's official application in September 2012. Furthermore, the governor of Croatian National Bank recently (March 2016) stated that Croatia would be the $20^{\text {th }}$ member of the euro area as soon as possible (Mus 2017). However, the country is obliged to be a member of the ERM II for at least two continuous years and fulfil each criterion of the Maas-
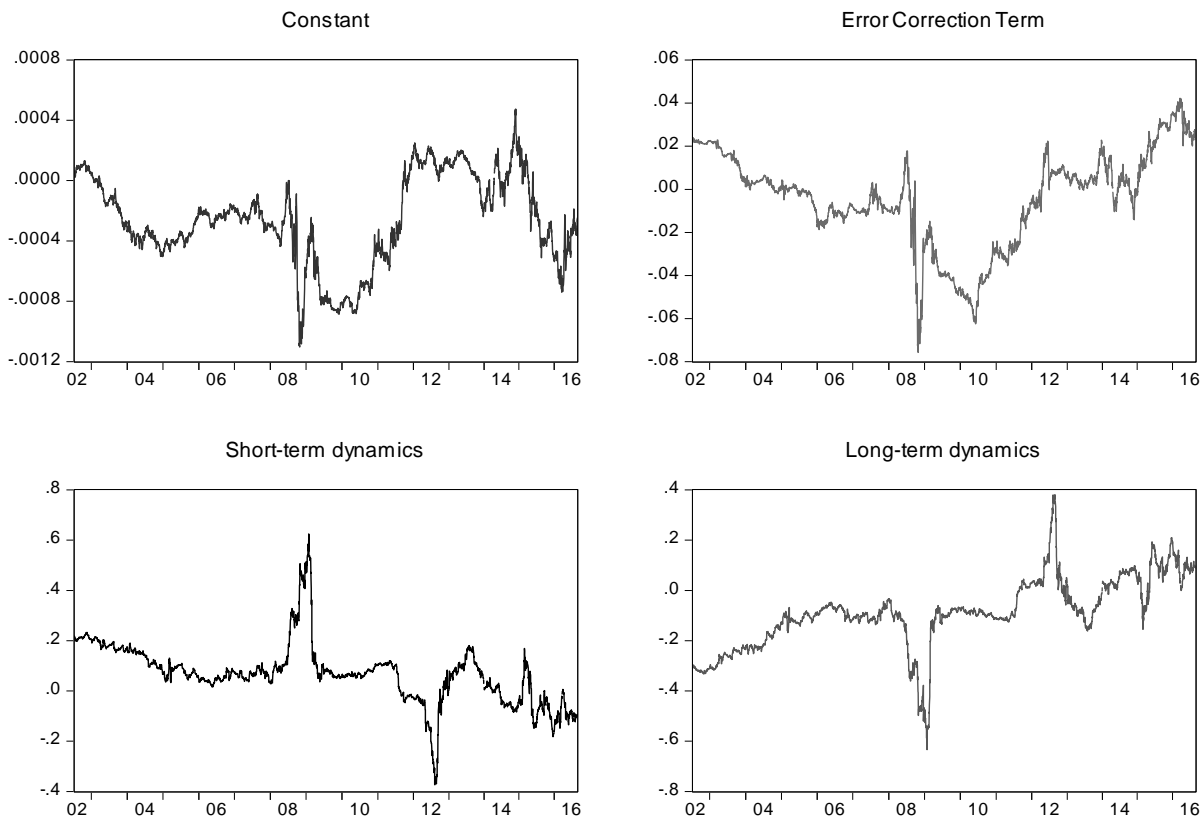

Figure 3. Rolling Regression Results of ECM (Croatia) 
tricht Treaty. The report of the ECB in 2016 stated that Croatia fulfils only 4 of the 7 Maastricht criteria and therefore the country is not ready to participate in the euro zone (ECB 2016). However, the CNB estimates that Croatia will be a member of the EMU by 2020. We observe that Croatia continuously expanded the economic and financial interactions with the euro area after its EU membership in 2013. Therefore, it is logical that the tendency of the negative long-term relationship between the two currencies decreases over time.

Figure 3 shows the empirical findings of the rolling regression estimation. We observe that the coefficient of short-term dynamics is positive, but it has a declining tendency. On the other hand, the coefficient of long-term dynamics expresses an increasing tendency. In particular, the long-term coefficient becomes positive after the accession of Croatia to the EU. The present results are consistent with the findings of the Error Correction Model, which have been displayed previously.

\section{Hungary}

We observe that the short-term dynamics of the euro on the Hungarian forint (HUF) increased after Hungary joined the EU ( $2^{\text {nd }}$ period $)$. However, we observe that there is no short-term euro impact on the Hungarian currency during the debt crisis in the euro area. The error correction term is statistically significant only during the $2^{\text {nd }}$ period. Thus, there is an adjustment speed back to equilibrium. We observe that the long-term effect of the euro on the HUF is negative through the total period. Nevertheless, the long-term impact of the euro on the Hungarian currency is zero during the first period, negative during the second period, and deeper negative during the third period. This may be because Hungary was not a member of the EU during the $1^{\text {st }}$ period. This means that there were limited trade and economic relationships between Hungary and the EU.

Table 6. Estimation results of ECM - HUF vs. EUR

\begin{tabular}{lcccc}
\hline Parameter & Total period & $1^{\text {st }}$ period & $2^{\text {nd }}$ period & $3^{\text {rd }}$ period \\
$\omega$ & 0.001 & 0.001 & -0.001 & -0.001 \\
& $(0.43)$ & $(0.27)$ & $(-2.49)^{*}$ & $(1.35)$ \\
$\psi$ & 0.050 & -0.155 & 0.112 & -0.004 \\
$\varphi$ & $(2.02)^{*}$ & $(-2.06)^{*}$ & $(3.23)^{*}$ & $(-1.10)$ \\
$\theta$ & -0.001 & -0.011 & -0.011 & -0.004 \\
& $(-0.89)$ & $(-1.32)$ & $(-2.56)^{*}$ & $(-0.93)$ \\
& -0.081 & 0.067 & -0.161 & -0.316 \\
& $(-2.32)^{*}$ & $(0.89)$ & $(-3.10)^{*}$ & $(2.23)^{*}$ \\
\hline
\end{tabular}

Note: $*$ statistically significant at the $0.05 \%$ level. 
Also, there is a negative long-term impact of the euro on HUF during the $2^{\text {nd }}$ period. This may be attributed to the following reasons. Successive Hungarian governments planned the participation of Hungary in the euro area as of January 1, 2012. However, that date was abandoned because of an excessively high budget deficit, inflation, and public debt (Matolcsy 2010). Specifically, the Hungarian government introduced austerity measures in late 2006 and an economic slowdown took place in 2007 and 2008. Also, in 2007, the deficit was reduced to less than 5\% (from 9.2\%) and approached the 3\% threshold in 2008. In the same year, analysts claimed that Hungary could join ERM II in 2010 or 2011, possibly adopting the euro in 2013, but more feasibly in 2014 or later, depending on euro zone crisis developments. In 2008, Hungary received financial assistance (a loan agreement) from the IMF, the EU, and the World Bank in order to confront the financial crisis of that time (Impey 2011). The imbalances of the Hungarian economy forced the government to abandon its plans for euro area participation. During the third period, a new government was elected in Hungary. The first goal of this Hungarian government was to implement more austerity measures in order to manage the macroeconomic factors. In 2011, the Hungarian government announced that the country was not yet ready to adopt the European common currency and they would not discuss the possibility until the public debt reached a $50 \%$ threshold (Matolcsy 2011). When the countries of the euro zone adopted the Euro Plus Pact on 25 March 2011, Hungary decided to go along with the United Kingdom, Sweden, and the Czech Republic and chose not to join the pact. In April 2013, the Hungarian government announced that euro adoption would not happen until the Hungarian purchasing power parity weighted GDP per capita had reached $90 \%$ of the euro zone average. However, it is estimated that this will take place after 2050, according to the currently available economic data (Jones 2016). Thus, in the light of the above, it is logical that the impact of the euro on the HUF is more negative during the third period. Finally, the Hungarian central bank (MNB) has followed a monetary policy similar to the ECB since 2004 (Kiss 2005). However, we do not observe the same economic responses between the two currencies. In fact, the HUF does not financially peg with the euro. According to our results, Hungary could not join the euro area in the near future.

Figure 4 presents the historical evolution of the ECM components through time. The main characteristic of the rolling regression's results is that the shortterm impact of the euro on the HUF is approximately zero, but there is a sense of slight positivity during the total period.

On the other hand, we observe that the long-term impact of the euro on the HUF is approximately zero. The empirical findings of the rolling regression methodology support the evidence of the ECM. 
Constant

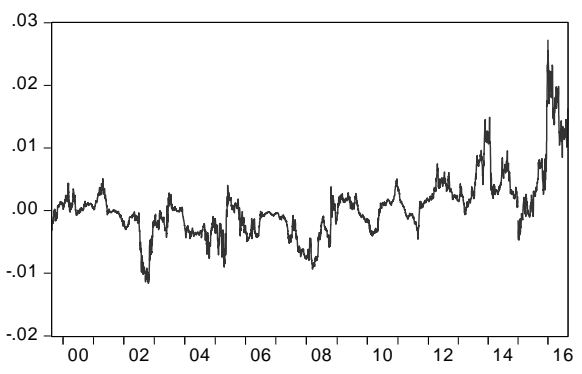

Short-term dynamics

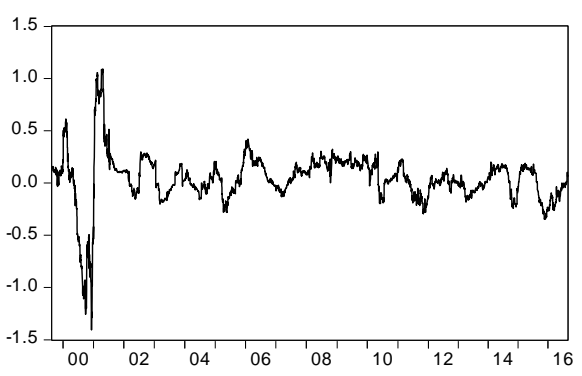

Error Correction Term

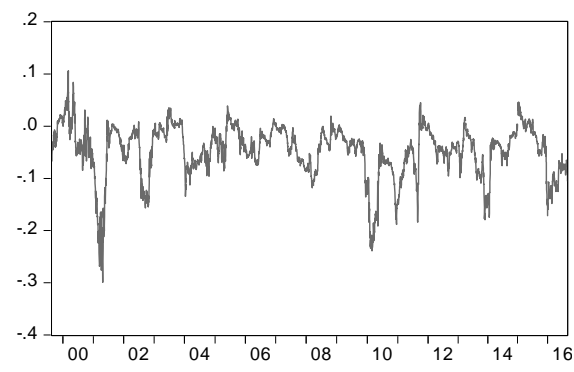

Long-term dynamics

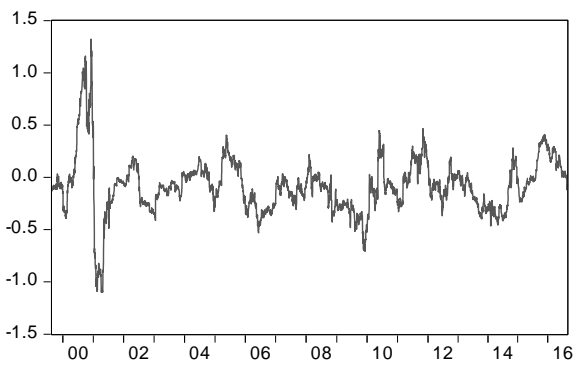

Figure 4. Rolling Regression Results of ECM (Hungary)

\section{Poland}

Table 7 presents the empirical findings of the ECM for Poland. Our evidence highly supports that there is a statistically significant positive relationship in the long run during the first period because Poland's exchange rate policy incorporated the parity against the euro as one of its main components until the decision in April 2000 to float the currency. The zloty (PLN) central parity was based on a partial peg to the euro (Morales 2000). A more accelerated convergence of interest rate and inflation to euro levels should in itself favour a stronger correlation between the currencies and the euro in the period prior to the country's formal accession to the EU. Moreover, the euro market has become even more important for exports from Poland in the aftermath of the Russian crisis of 1998 (Morales 2000). During the second period, we observe that there is a positive impact of the euro on the PLN in the short run. Also, there is a neutral long-term relationship between these two currencies. This condition may be due to the monetary policy of the Polish National Bank (Narodowy Bank Polski, PNB). If a country keeps its interest rates at a relatively high level, it usually attracts large short-term capital 
Table 7. Estimation Results of ECM - PLN vs. EUR

\begin{tabular}{lcccc}
\hline Parameter & Total period & $1^{\text {st }}$ period & $2^{\text {nd }}$ period & $3^{\text {rd }}$ period \\
$\omega$ & 0.001 & 0.001 & -0.001 & 0.001 \\
& $(0.25)$ & $(0.684)$ & $(-1.10)$ & $(1.31)$ \\
$\psi$ & -0.027 & -0.029 & 0.052 & -0.078 \\
$\varphi$ & $(-1.33)$ & $(-0.761)$ & $(2.67)^{*}$ & $(1.98)^{*}$ \\
$\theta$ & -0.004 & -0.004 & -0.005 & -0.001 \\
& $(-2.14)^{*}$ & $(-0.82)$ & $(-1.99)^{*}$ & $(-1.16)$ \\
& 0.152 & 0.311 & -0.185 & 0.343 \\
\hline
\end{tabular}

Note: * statistically significant at the $0.05 \%$ level.

flows and the currency of the country appreciates. In 2002-2003, the difference between interest rate levels decreased, and the zloty depreciated. In subsequent years, there no longer was such a clear relationship (Bojanowska - MacDonald 2009). In 2007-2008, the zloty exchange rate fluctuated in accordance with the interest rate parity condition, but towards the end of 2008, the trend of the EUR/ PLN exchange rate was reversed in consequence of the global financial crisis and foreign investors' growing aversion to investing in emerging markets (Bojanowska - MacDonald 2009). In 2010, the zloty was appreciating, which could not be justified by changes in interest rates. Also, Poland's accession to the EU in May 2004 was an important factor (Arratibel - Michaelis 2014). During the third period, it is clear that there is a negative effect of the euro on the PLN, possibly because the policy of the Polish government and the governor of the PNB is to delay participation in the euro area. The main reason behind this decision is the debt crisis in the euro zone after 2010 (Arratibel - Michaelis 2014). Therefore, euro membership might be positive for the Polish economy, according to the Polish government. In addition, the governor of the PNB voiced many concerns regarding speculations over the PLN when the currency would enter the ERM II of the ECB. The Polish government does not intend to participate in the EMU before 2020. On the other hand, there is a positive long-term linkage between the euro and the PLN during the third period, due to the similar monetary policy (interest rates) implemented by the ECB and the PNB after 2010 (Arratibel Michaelis 2014). An important factor is the increase of trade relationship between Poland and the euro area. In particular, the trade and economic linkages of Poland are greater with Germany, Slovakia, and Lithuania due to common borders. However, Germany is the most important trade partner of Poland with $€ 50$ billion in exports (World Bank 2016). Furthermore, the coefficient of error correction term expresses that a downturn adjustment back to equilibrium during the $2^{\text {nd }}$ period is expected. Essentially, we have discovered important evidence which supports that there is a positive long-term tendency between the euro and the PLN in the distant 

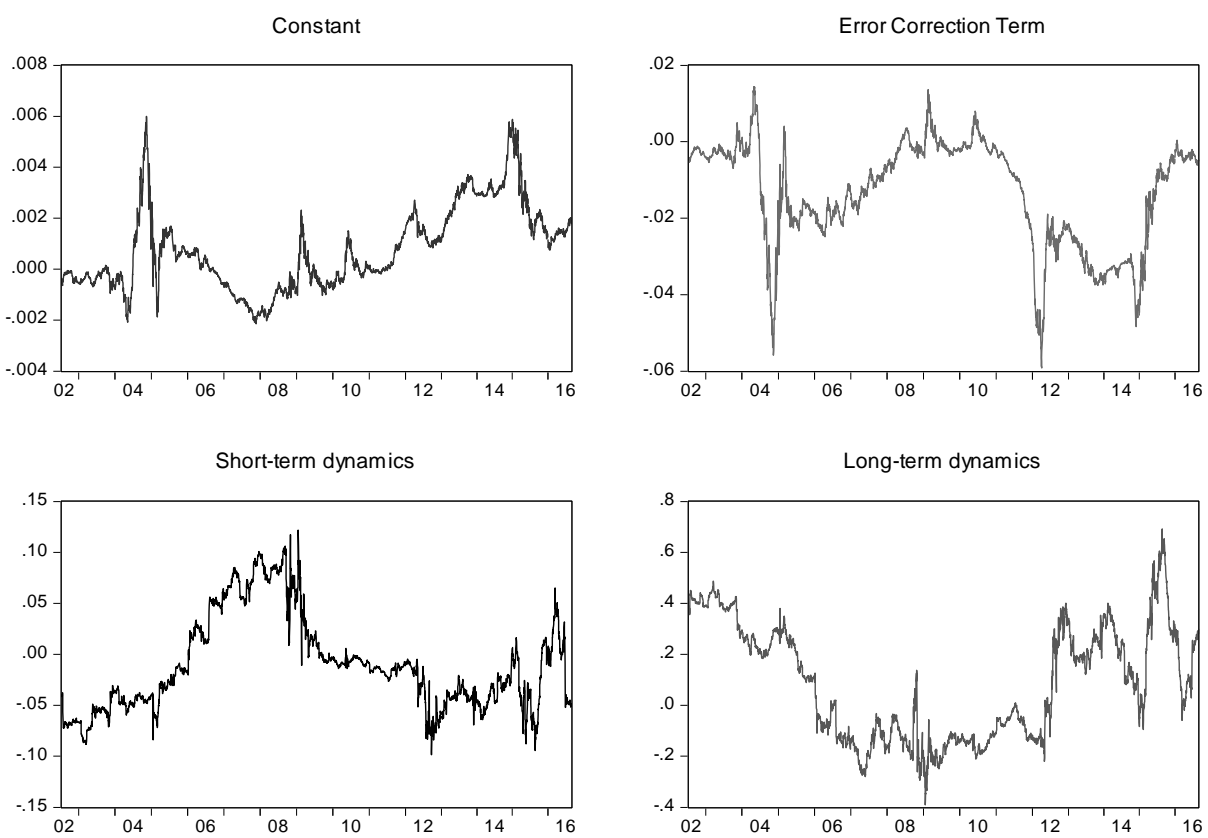

Figure 5. Rolling Regression Results of ECM (Poland)

future. Consequently, Poland is ready to join the euro zone from a financial point of view. Also, Polish public opinion is in favour of euro adoption and the country has already fulfilled the Maastricht criteria, except the ERM II participation. In fact, euro area membership is a political choice of the Polish government.

Figure 5 presents the empirical findings of the rolling regression estimation. We observe that the coefficient of short-term dynamics is positive until 2008. After the global financial crisis of 2008, there is a declining tendency. On the other hand, the coefficient of long-term dynamics expresses an increasing positive tendency after 2010. Especially, the long-term coefficient becomes positive after the presence of the debt crisis in the euro area. The present results are consistent with the findings of the ECMl shown above.

\section{Romania}

Table 8 shows that the short-term dynamics between the euro and the Romanian Leu (RON) was strictly negative when Romania was not a member of the EU. During the first period, Romania had limited trade relationships with the EU. At the time, EU had not been expanded to the Balkan Peninsula, except for Greece. 
Table 8. Estimation results of ECM - RON vs. EUR

\begin{tabular}{lcccc}
\hline Parameter & Total period & $1^{\text {st }}$ period & $2^{\text {nd }}$ period & $3^{\text {rd }}$ period \\
$\omega$ & 0.001 & 0.001 & 0.001 & 0.001 \\
& $(2.90)^{*}$ & $(2.85)^{*}$ & $(-0.19)$ & $(1.54)$ \\
$\psi$ & -0.116 & -0.236 & -0.107 & -0.086 \\
& $(-5.93)^{*}$ & $(-6.95)^{*}$ & $(-3.32)^{*}$ & $(-1.30)$ \\
$\varphi$ & -0.002 & -0.003 & -0.002 & -0.001 \\
& $(-4.94)^{*}$ & $(-3.33)^{*}$ & $(-1.34)$ & $(-1.22)$ \\
$\theta$ & 0.085 & 0.013 & 0.069 & 0.112 \\
& $(3.83)^{*}$ & $(0.41)$ & $(1.94)$ & $(2.01)^{*}$ \\
\hline
\end{tabular}

Note: * statistically significant at the $0.05 \%$ level.

Also, Romania maintained economic and trade linkages with Russia due to communist regime in the country until 1989 . During the second period, the short-term impact of the euro on the RON is less negative than in the first period. In addition, the long-term effect is neutral. This is reasonable because Romania became a member of the EU at the end of this period. There were no strong economic linkages between Romania and the EU (Angeloni et al. 2003). Specifically, after accession to the EU, the Romanian National Bank (Banca Nationala a Romaniei) started to follow a similar interest rate policy, such as the ECB. Moreover, the short-term impact of the euro on the RON became neutral during the third period. The debt crisis of 2010 in the euro zone does not influence the relationship between the two currencies.

The coefficient of error correction term $(\varphi)$ expresses that a downturn adjustment during the following period is expected. The adjustment speed is extremely low and close to zero. The long-term impact of the euro on the Romanian currency seems to be positive during the third period. We observe that the trend is an upturn. Essentially, the positive relationship between these two currencies means that the RON follows the long-term economic behaviour of the euro. This indicates that Romania's EU membership influenced positively the relationship between its currency and the euro. During the third period, we observe that the National Bank of Romania essentially follows the monetary policy of the ECB, especially the regime of interest rates (Popescu 2013). Also, the trade relationship of Romania with the EU has been strengthened. For instance, the three top import partners of Romania are Germany $(19,1 \%)$, Italy $(10,8 \%)$, and Hungary $(7,8 \%)$, while the three top export partners of Romania are Germany $(21.5 \%)$, Italy (11,4\%), and France (7,2\%) in 2016 (World Bank 2016). Finally, it is a strong political intention of the Romanian government to join the euro area in the near future. However, there are many concerns about the long-term condition of the Romanian economy in the euro. For instance, the participation of Greece in the EMU approved as an incorrect decision. The Greek economy is very vulner- 

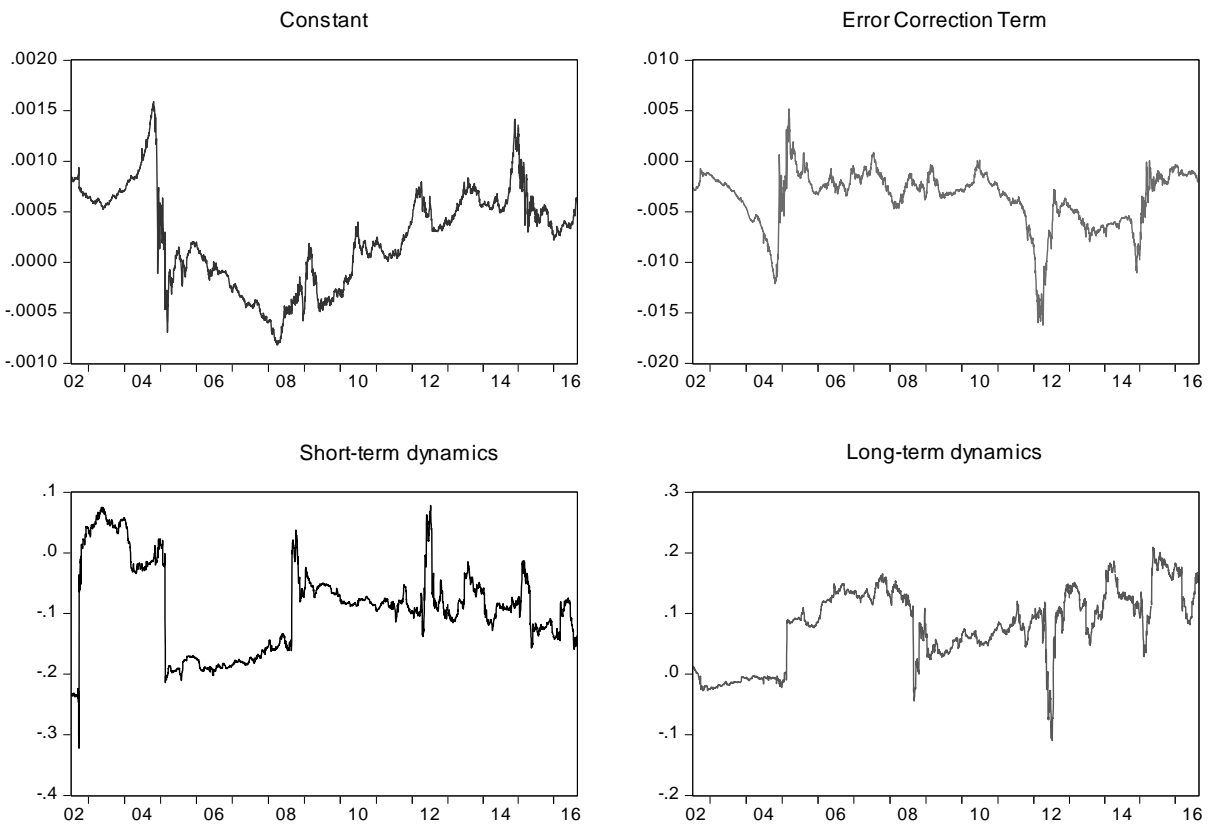

Figure 6. Rolling Regression Results of ECM (Romania)

able to external financial shocks in the lack of successful safeguards. In addition, the Romanian banking sector is linked to the Greek banking industry because of the presence of Greek banking institutions in the country. Therefore, the participation of Romania in the EMU would strengthen the relationship between these countries, while we may observe an increase of the transitory effect due to the common currency. The most recent (June 2016) ECB report declares that Romania fulfils each convergence criterion of the Maastricht Treaty. Therefore, Romania needs only the two-year participation in the ERM II before adopting the euro (ECB 2016).

Figure 6 presents the results of the rolling regression for Romania. The rolling regression shows that the short-term dynamics coefficient is negative, especially after the EU membership. This tendency does not change during the third period. On the other hand, the long-term dynamics coefficient follows a different behaviour. The value of the long-term coefficient is positive after Romania's unofficial (acceding country) EU membership (May 2004). Moreover, we observe that the long-term tendency between the euro and the RON seems to be positive from 2004 to 2016 . The trend is increasingly more augmentative through time. The empirical evidence of the rolling regression is wholly consistent with the findings of the ECM. 


\subsection{ECM-APARCH $(1,1)$ results}

For the purpose of this paper, we developed the APARCH $(1,1)$ model with 1 asymmetric order and random power effect ( $\delta$ parameter). The asymmetric volatility phenomenon (sometimes known as AVP) is a market dynamic that shows that there are higher market volatility levels in market downswings than in market upswings (Wu 2001).

Persistence in volatility of variable returns is one of the common "stylised facts" when it comes to analysing time series. In fact, volatility should have a long memory. This means that the information flow is slow and therefore news coming to the markets are not absorbed immediately, but with some delay, leading to "long-term-adjustments".

"Leverage effect" refers to the well-established relationship between variables returns and both implied and volatility: volatility increases when a security price falls. A standard explanation ties the phenomenon to the effect of a change in the market valuation of a security, with an increase in leverage producing an increase in variable volatility (Karanasos - Kim 2006).

\section{Czech Republic}

Table 9 presents the empirical results of an $\operatorname{APARCH}(1,1)$ model by using the natural logarithmic value of the nominal exchange rate of the CZK/USD as the dependent variable and the natural logarithmic value of the nominal exchange rate of the EUR/USD as the control variable in the mean equation. The $\delta$ parameter represents the power of the APARCH model.

We observe that its value is close to 2 for each period. This means that the APARCH model behaves as a GARCH model. The sum of parameter $\alpha(\mathrm{ARCH}$

Table 9. Estimation Results of Asymmetric Power ARCH - CZK vs. EUR

\begin{tabular}{lcccc}
\hline Parameter & Total period & $1^{\text {st }}$ period & $2^{\text {nd }}$ period & $3^{\text {rd }}$ period \\
$\omega$ & 0.001 & 0.001 & 0.001 & 0.001 \\
& $(1.20)$ & $(0.87)$ & $(0.56)$ & $(0.70)$ \\
$\alpha$ & 0.034 & 0.023 & 0.031 & 0.296 \\
& $(11.11)^{*}$ & $(0.96)$ & $(4.01)^{*}$ & $(4.57)^{*}$ \\
$\gamma$ & -0.028 & -0.251 & 0.092 & -0.183 \\
$\beta$ & $(-0.69)$ & $(-1.05)$ & $(0.99)$ & $(-1.21)$ \\
& 0.966 & 0.900 & 0.961 & 0.967 \\
$\delta$ & $(289.19)^{*}$ & $(8.50)^{*}$ & $(173.20)^{*}$ & $(150.58)^{*}$ \\
& 1.66 & 1.74 & 2.21 & 1.55 \\
\hline
\end{tabular}

Note: * statistically significant at the $0.05 \%$ level. 
effect) and parameter $\beta$ (GARCH effect) is close to unity, indicating that the Czech koruna's volatility shocks are quite persistent. The coefficient of the GARCH effect is lower than the one expressing that the past news on volatility is significant. The magnitude of lagged conditional variance is high. This means that long memory exists in variance. The $\gamma$ parameter shows the leverage effect, which is zero during each period. This indicates that there is no asymmetry at the news impact and that bad news of the euro influences the volatility of the Czech koruna to a greater extent. The bad news of the euro shows the same impact as the good news. In fact, the news responses of the euro seem to be symmetric on the Czech koruna during the entire examined period.

\section{Croatia}

Table 10 shows that for Croatia, the $\delta$ parameter is close to 1 , approximately for each period, expressing that the APARCH model mutates to the TGARCH model. Also, a GARCH model takes place during the $2^{\text {nd }}$ period. The $\alpha$ coefficient presents the size effect and it is positive at each period. If volatility is sensitive to large shocks, one can expect $\alpha$ to be positive and significant. Thus, large shocks of both signs will increase volatility.

The sum of the ARCH and GARCH effects is close to unity for each period, indicating that Croatian kuna's volatility shocks are quite persistent. We discovered that an increasing long memory effect exists. The leverage effect does not take place during the $2^{\text {nd }}$ period. This means that the news of the euro has no effect on the conditional variance of the HRK. In fact, the news responses of the euro seem to be symmetric on the HRK during this sub-period. The bad news of the euro shows the same impact as the good news. This is quite logical because Croatia became a member of the EU in 2013. Additionally, the $\gamma$ parameter is positive

Table 10. Estimation Results of Asymmetric Power ARCH - HRK vs. EUR

\begin{tabular}{lcccc}
\hline Parameter & Total period & $1^{\text {st }}$ period & $2^{\text {nd }}$ period & $3^{\text {rd }}$ period \\
$\omega$ & 0.001 & 0.001 & 0.001 & 0.001 \\
& $(0.89)$ & $(1.01)$ & $(0.82)$ & $(0.77)$ \\
$\alpha$ & 0.033 & 0.053 & 0.035 & 0.032 \\
$\gamma$ & $(9.80)^{*}$ & $(1.02)$ & $(5.24)^{*}$ & $(5.64)^{*}$ \\
$\beta$ & -0.133 & 0.999 & 0.069 & -0.221 \\
& $(-2.87)^{*}$ & $(27.13)^{*}$ & $(1.17)$ & $(2.55)^{*}$ \\
$\delta$ & 0.967 & 0.222 & 0.964 & 0.967 \\
& $(255.06)^{*}$ & $(0.597)$ & $(180.35)^{*}$ & $(131.88)^{*}$ \\
& 1.33 & 0.44 & 1.81 & 0.89 \\
\hline
\end{tabular}

Note: * statistically significant at the $0.05 \%$ level. 
during the $1^{\text {st }}$ period. Particularly, the bad news of the euro has a larger impact on the volatility of the HRK than the good news. A different effect takes place during the $3^{\text {rd }}$ period, when the good news of the euro seems to have greater effect on the volatility of the HRK. In fact, the news responses of the euro are asymmetric during this sub-period.

\section{Hungary}

In Table 11, the $\delta$ parameter expresses that a TGARCH model exists during the $1^{\text {st }}$ and the $3^{\text {rd }}$ periods. However, a GJR-GARCH takes places during the $2^{\text {nd }}$ period because the $\delta$ coefficient is close to 2 . The GJR-GARCH model is similar to the TGARCH model (Glosten et al. 1993) and the QGARCH model (Sentana 1995). The ARCH effect is positive during the periods, but its magnitude decreases through time. This means that the volatility of the Hungarian forint (HUF) is less sensitive to large shocks of the euro after the country accession to the EU.

Table 11. Estimation Results of Asymmetric Power ARCH - HUF vs. EUR

\begin{tabular}{lcccc}
\hline Parameter & Total period & $1^{\text {st }}$ period & $2^{\text {nd }}$ period & $3^{\text {rd }}$ period \\
$\omega$ & 0.001 & 0.001 & 0.001 & 0.001 \\
& $(1.15)$ & $(0.39)$ & $(0.62)$ & $(0.64)$ \\
$\alpha$ & 0.039 & 0.013 & 0.048 & 0.036 \\
& $(9.97)^{*}$ & $(3.91)^{*}$ & $(5.16)^{*}$ & $(5.73)^{*}$ \\
$\gamma$ & -0.291 & -0.999 & -0.199 & 0.191 \\
$\beta$ & $(-4.28)^{*}$ & $(-5.43)^{*}$ & $(-2.12)^{*}$ & $(-1.22)$ \\
& 0.963 & 0.986 & 0.946 & 0.964 \\
$\delta$ & $(241.70)^{*}$ & $(93.75)^{*}$ & $(126.86)^{*}$ & $(159.50)^{*}$ \\
& 1.24 & 0.813 & 1.53 & 0.954 \\
\hline
\end{tabular}

Note: * statistically significant at the $0.05 \%$ level.

The coefficient of $\beta$ parameter has an upturn trend during the periods. The persistency of the conditional variance of the HUF against the euro's shocks seems to increase continuously. The leverage effect ( $\gamma$ parameter) is negative, but it has a decreasing tendency. This effect becomes stronger through time, expressing that the euro has less influence on the Hungarian currency in the long run. Actually, the news responses of the euro are asymmetric.

\section{Poland}

In Table 12, the $\delta$ parameter for Poland is close to 1 during each period expressing that there is a TGARCH model. The size effect $(\alpha)$ is positive during the examined periods, but the tendency is downward. Therefore, the PLN is less sensitive 
Table 12. Estimation Results of Asymmetric Power ARCH - PLN vs. EUR

\begin{tabular}{lcccc}
\hline Parameter & Total period & $1^{\text {st }}$ period & $2^{\text {nd }}$ period & $3^{\text {rd }}$ period \\
$\omega$ & 0.001 & 0.001 & 0.001 & 0.002 \\
$\alpha$ & $(2.57)^{*}$ & $(1.04)$ & $(1.19)$ & $(1.34)$ \\
& 0.010 & 0.159 & 0.074 & 0.045 \\
$\gamma$ & $(18.12)^{*}$ & $(5.30)^{*}$ & $(8.95)^{*}$ & $(5.24)^{*}$ \\
$\beta$ & -0.271 & -0.589 & -0.221 & -0.456 \\
& $(-7.24)^{*}$ & $(-4.41)^{*}$ & $(-4.01)^{*}$ & $(-3.77)^{*}$ \\
$\delta$ & 0.903 & 0.759 & 0.928 & 0.955 \\
& $(157.12)^{*}$ & $(17.35)^{*}$ & $(128.71)^{*}$ & $(132.38)^{*}$ \\
& 1.02 & 0.93 & 1.27 & 0.29 \\
\hline
\end{tabular}

Note: * statistically significant at the $0.05 \%$ level.

to large shocks of the euro. Also, the GARCH effect indicates long memory in the variance. The magnitude is higher after Poland's accession to the EU. The volatility persistence of the PLN against the euro shocks is high. The $\gamma$ parameter is negative during the examined periods, but the effect declines over time. Particularly, the good news of the euro has a greater impact on the conditional variance instead of the bad news. The leverage effect is greater during the first period when Poland was not a member of the EU, but the effect sign remains almost stable. Actually, the bad news responses of the euro influence more the economic reaction of the PLN during the entire examined period.

\section{Romania}

In Table 13, we used the errors of the Romania ECM model (mean equation) at the variance equation of the APARCH model. The $\delta$ parameter expresses that there is a TGARCH model during each period. The sum of the ARCH and GARCH coefficients is close to unity for each period, expressing that the RON volatility is quite persistent to the shocks of the euro.

The size of the GARCH coefficient rose between the $1^{\text {st }}$ and the $2^{\text {nd }}$ period. Therefore, an increase of the long memory in the variance took place. This is perhaps related to Romania's accession to the EU in 2007. The $\gamma$ parameter represents the leverage effect on conditional variance. The leverage effect is negative only in the $3^{\text {rd }}$ period, expressing that the good news of the euro has a higher effect on the volatility of the RON. Also, the leverage effect is positive only in the $2^{\text {nd }}$ period, expressing that the bad news of the euro has higher effect on the volatility of the RON. Finally, there is no leverage effect during the $1^{\text {st }}$ period. This means that the news of the euro does not influence the conditional variance of the RON. 
Table 13. Estimation Results of Asymmetric Power ARCH - RON vs. EUR

\begin{tabular}{lcccc}
\hline Parameter & Total period & $1^{\text {st }}$ period & $2^{\text {nd }}$ period & $3^{\text {rd }}$ period \\
$\omega$ & 0.001 & 0.001 & 0.001 & 0.001 \\
$\alpha$ & $(3.29)^{*}$ & $(1.85)$ & $(1.599)$ & $(0.77)$ \\
$\gamma$ & 0.111 & 0.562 & 0.076 & 0.036 \\
& $(29.97)^{*}$ & $(18.52)^{*}$ & $(8.72)^{*}$ & $(6.19)^{*}$ \\
$\beta$ & -0.019 & 0.027 & 0.138 & -0.325 \\
& $(-0.71)$ & $(0.70)$ & $(2.64)^{*}$ & $(-2.89)^{*}$ \\
$\delta$ & 0.906 & 0.491 & 0.931 & 0.964 \\
& $(268.80)^{*}$ & $(24.76)^{*}$ & $(137.98)^{*}$ & $(164.01)^{*}$ \\
& 0.836 & 0.91 & 1.29 & 0.674 \\
\hline
\end{tabular}

Note: * statistically significant at the $0.05 \%$ level.

\section{CONCLUSION AND DISCUSSION}

The purpose of our research is to investigate whether the post-communist countries of the EU are mature enough to join the European Monetary Union. Essentially, we employed the methodology of Wilfling (2009) by using the nominal exchange rates as an empirical instrument in order to answer our research questions. The idea of Stoupos - Kiohos (2017) was used as an auxiliary empirical method in order to produce our evidence. Our empirical findings are based on three parameters: volatility shocks persistence, leverage effects, and short-term/ long-term dynamic relationships.

The Error Correction Model highly supports that there is a positive dynamic linkage between the euro and the Czech koruna, Hungarian forint and Croatian kuna, especially after the EU accession. We studied the debt crisis of 2010 and found that it had no impact on the short-term relationship between the euro and the PLN and the RON. The long-term impact of the euro on the Czech koruna, the Croatian kuna, and the Hungarian forint is strictly negative. However, a significant improvement (positive tendency) takes place through time for each country (the Czech Republic and Croatia), except Hungary. Therefore, there is strong evidence that supports that these countries are not ready for euro zone participation from a financial aspect. On the other hand, we observed that there is an increasing positive linkage between the euro and the PLN as well as the RON in the long run. Finally, the results of the rolling regression test are wholly consistent with the evidence of the ECM.

Furthermore, the results of ECM-APARCH $(1,1)$ suggest that there is high volatility persistence of each currency against the volatility shocks of the euro. The leverage effect was zero for the Czech Republic during the entire examined 
period. There are symmetric effects between the bad and the good news of the euro on the CZK. On the other hand, the $\gamma$ parameter is positive during the $1^{\text {st }}$ period for Croatia. Particularly, the bad news of the euro has a larger impact on the volatility of the HRK than the good news. A different effect takes place during the $3^{\text {rd }}$ period when the country became a member of the EU. The leverage effect for Hungary is negative and has a falling tendency. This indicates that the good news of the euro has a larger impact on the volatility of the HUF. Thus, the euro has less influence on the Hungarian forint through time. In addition, a similar effect occurs between the PLN and the euro. Finally, we discovered that there is no leverage effect between the $1^{\text {st }}$ period for Romania. The leverage effect is negative during the $3^{\text {rd }}$ period when the country became a member of the European Union.

On the other hand, the dynamic linkages between the exchange rates is not the only indicator which is able to strictly indicate that a member state of the EU is eligible to become part of the euro area. The short- and long-term economic relationships of the euro against the currencies of the post-communist countries is only one side of the coin. This means that in the future we should explore the economic behaviour of other parameters such as trade flows, the real exchange rate, the consumer price index, and even the political and economic stability of each country. If a meticulous examination of each economic parameter is performed, we could definitely determine whether these countries can adopt the euro as their currency. However, the empirical investigation of these parameters is beyond the scope of this research.

Finally, our findings are in line with the results of Economidou - Kool (2009). We also agree with the evidence of Koukouritakis et al. (2015). On the other hand, we discovered that our results contrast with the findings of Chang - Tzeng (2011) as well as Podkaminer's (2016) claims because we highly support the idea that European monetary integration should be continued in the future. Our opinion is that the post-communist countries should continue to improve their economic and political relations with other members of the Union in order to adopt this exchange rate regime (euro adoption) when they are financially apt. Romania and Poland should focus more in this direction if they wish to participate in the EMU without any collateral losses. Otherwise, they would face the fate of Greece because the euro is a really strong currency and it is not suitable for the weak and vulnerable economies of Europe. 


\section{REFERENCES}

Angeloni, I. - Kashyap, A. K. - Mojon, B. (2003): Monetary Policy Transmission in the Euro Area: A Study by the Eurosystem Monetary Transmission Network. Cambridge: Cambridge University Press.

Arrabitel, O. - Michaelis, H. (2014): The Impact of Monetary Policy and Exchange Rate Shocks in Poland: Evidence from a Time-Varying VAR. ECB Working Paper Series, No.1636.

Banerjee, A. - Lumsdaine, R. - Stock, J. H. (1992): Recursive and Sequential Tests of the Unit Root and Trend Break Hypothesis: Theory and International Evidence, Journal of Business and Economic Statistics, 10(3): 271-288.

Bera, A. K. - Higgins, M. L. (1993): ARCH Models: Properties, Estimation and Testing. Journal of Economic Surveys, 7(4): 305-362.

Bojanowska, J. - MacDonald, R. (2009): The Behavioural Zloty/Euro Equilibrium Exchange Rate. National Bank of Poland Working Papers, No. 55.

Bollerslev, T. (1986): Generalised Autoregressive Conditional Heteroscedasticity. Journal of Econometrics, 31(3): 307-328.

Chang, T. - Tzeng, H. W. (2011): Long-Run Purchasing Power Parity with Asymmetric Adjustment: Further Evidence from Nine Transition Countries. Economic Modelling, 28: 1383-1391.

Ding, Z. - Granger, C. - Engle, R. (1993): A Long Memory Property of Stock Market Returns and a New Model. Journal of Empirical Finance, 1(1): 83-106.

Economidou, C. - Kool, C. (2009): European Economic Integration and (A)symmetry of Macroeconomic Fluctuations. Economic Modelling, 26(4): 778-787.

Engle, R. F. (1982): Autoregressive Conditional Heteroscedasticity with Estimates of the Variance of United Kingdom Inflation. Econometrica, 50(4): 987-1007.

Engle, R. F. - Granger, C. W. (1987): Co-Integration and Error Correction: Representation, Estimation and Testing. Econometrica, 55(2): 251-276.

European Central Bank (2016): Convergence Report. ECB Reports.

Glosten, L. R. - Jaganathan, R. - Runkle, D. (1993): On the Relation between the Expected Value and the Volatility of the Normal Excess Return on Stocks. Journal of Finance, 48(5): 17791801.

Harper, J. (2017): Czech Republic is Not Preparing to Join Eurozone. Central European Financial Observer, 28 January 2017.

Impey, J. (2011): Hungary Seeks Financial Help from the EU and the IMF. Deutsche Welle, 21 November 2011.

International Monetary Fund (2015): World Economic Outlook. IMF Reports, No.1: 1-32.

Jansson, E. (2005): Croatia's Central Bank Fights Pressure on Euro - Peg. Financial Times, 07 June 2005.

JP Morgan (2009): Questioning the US Dollar's Status as a Reserve Currency. JP Morgan Asset Management Reports, No.1: 1-8.

Johansen, S. - Mosconi, R. - Nielsen, B. (2000): Cointegration Analysis in the Presence of Structural Breaks in the Deterministic Trend. The Econometrics Journal, 3(2): 216-249.

Jones, G. (2016): Orban Says Hungarian Faces Serious Challenge in Euro Decision. Reuters, 29 February 2016.

Karanasos, M. - Kim, J. (2006): A Re-Examination of the Asymmetric Power ARCH Model. Journal of Empirical Finance, 13(1): 113-128.

Kiss, G. (2005): Monetary Policy Issues in Hungary on the Eve of EU Membership. Bank of International Settlements, 23: 156-160. 
Koukouritakis, M. - Papadopoulos, A. - Yannopoulos, A. (2015): Linkages between the Eurozone and the South-Eastern European Countries: A Global VAR Analysis. Economic Modelling, 48: $129-154$.

Lee, J. - Strazicich, M. C. (2003): Minimum Lagrange Multiplier Unit Root Test with Two Structural Breaks. Review of Economics and Statistics, 85(4): 1082-1089.

Maican, F. - Sweeny, R. (2013): Real Exchange Rate Adjustment in European Transition Countries. Journal of Banking \& Finance, 37(3): 907-926.

Martin, K. (2017): Czech Central Bank Removes Currency Cap. Financial Times, 6 April 2017.

Matolcsy, Gy. (2010): Hungary: Euro is Possible in 2020. Világgazdaság, 04 March 2010.

Matolcsy, Gy. (2011): Hungary May Name Euro Entry Target Date in 2012. Bloomberg, 08 September 2011.

Morales, A. (2000): Czech Koruna and Polish Zloty Currency Options: Information Content and EU - Accession Implications. IMF Working Paper, No. 91.

Muller, R. - Hovet, J. (2017): Buoyant: Czech Economy Lets Central Bank Scrap Crown Cap. Reuters, 6 April 2017.

Mus, J. (2017): Join or Not to Join. The Eurozone Dilemma in Croatia. Central European Financial Observer, 22 February 2017.

Popescu, V. (2013): The Analysis of Monetary Policy Effects with Emphasis on Monetary Policy Strategy Types. A VAR Approach. Romanian Economic Journal, 16(47): 57-74.

Podkaminer, L. (2016): Economic Disintegration of the European Union: Not Unavoidable, but Probable. Acta Oeconomica, 66(1): 49-60.

Sentana, E. (1995): Quadratic ARCH Models. Review of Economic Studies. 62(4): 639-661.

Stoupos, N. - Kiohos, A. (2017): EU Unification and Linkages among the European Currencies: New Evidence from the EU and the EEA. Research in International Business and Finance, 41: $28-36$.

Wilfling, B. (2009): Volatility Regime-Switching in European Exchange Rates Prior to Monetary Unification. Journal of International Money and Finance, 28: 240-270.

World Bank (2016): World Integrated Trade Solution. World Bank Database.

Wu, G. (2001): The Determinants of Asymmetric Volatility. The Review of Financial Studies, 14(3): $837-859$.

Zakoian, J. M. (1994): Threshold Heteroskedastic Models. Journal of Economic Dynamics and Control, 18(5): 931-955. 